Article

\title{
Strength Time-Varying and Freeze-Thaw Durability of Sustainable Pervious Concrete Pavement Material Containing Waste Fly Ash
}

\author{
Hanbing Liu ${ }^{1}$, Guobao Luo ${ }^{1}{ }^{(\mathbb{C}}$, Longhui Wang ${ }^{2}$ and Yafeng Gong ${ }^{1, *}$ \\ 1 College of Transportation, Jilin University, Changchun 130025, China; liuhb@jlu.edu.cn (H.L.); \\ luogb17@mails.jlu.edu.cn (G.L.) \\ 2 China Construction Eighth Engineering Division Corp Ltd, Shanghai 200135, China; protein1@163.com \\ * Correspondence: gongyf@jlu.edu.cn; Tel.: +86-0431-8509-5446
}

Received: 27 November 2018; Accepted: 24 December 2018; Published: 31 December 2018

\begin{abstract}
Pervious concretes, as sustainable pavement materials, have great advantages in addressing a number of environmental issues. Fly ash, as the industrial by-product waste, is the most commonly used as cement substitute in concrete. The objective of this paper is to study the effects of waste fly ash on properties of pervious concrete. Fly ash was used to replace cement with equivalent volume method at different levels (3\%, $6 \%, 9 \%$, and $12 \%)$. The control pervious concrete and fly ash modified pervious concrete were prepared in the laboratory. The porosity, permeability, compressive strength, flexural strength, and freeze-thaw resistance of all mixtures were tested. The results indicated that the addition of fly ash decreased the early-age $(28 \mathrm{~d})$ compressive strength and flexural strength, but the long-term $(150 \mathrm{~d})$ compressive strength and flexural strength of fly ash modified pervious concrete were higher than that of the early-age. The adverse effect of fly ash on freeze-thaw resistance of pervious concrete was observed when the fly ash was added. The porosity and permeability of all pervious concrete mixtures changed little with the content of fly ash due to the use of equal volume replacement method. Although fly ash is not positive to the properties of pervious concrete, it is still feasible to apply fly ash as a substitute for cement in pervious concrete.
\end{abstract}

Keywords: pervious concrete; fly ash; time-varying strength; freeze-thaw resistance; permeability

\section{Introduction}

Pervious pavement plays an important role in urban rainwater management system. At the same time, it is of great significance to the future development of the urbanization [1]. In urban construction, large area of the city's original soil surface has been coated with cement, concrete, and other impervious surfaces [2]. The public places such as sidewalks, open-air parking lots and square, were also covered by stone or cement brick. Impervious surface has a significant adverse impact on urban ecology and climate environment while improving traffic and road conditions and beautifying the environment [3-5]. In general, summer is a season of heavy rains in China. The serious water accumulation has been occurred in many cities, which caused many disasters, such as traffic jams, power outages, and flooded houses [6-8]. The main reason for this is that the urban road surface is impervious [9]. The pervious pavement is an effective method to balance the urban ecosystem. The rainwater can penetrate into the ground from the pervious pavement and cause the groundwater level to rise rapidly [10]. The pervious pavement is the connecting passage between the underground and the ground, so that the ground is warm in winter and cool in summer, which can increase the comfort of urban living [11]. In addition, due to the large number of pores and large specific surface area of pervious pavement, it has strong adsorption capacity for dust, which can reduce dust pollution. 
However, in order to prevent voids from being clogged, regular cleaning is needed. On the other hand, the noise caused by vehicles can be well absorbed by the pores of pervious pavement $[12,13]$. Some developed countries began to investigate and develop pervious pavement materials in the 1970s and applied them to sidewalks, bicycle lanes, public square, open-air parking lots, park roads, shoulder and central divider [14]. It has increased the permeable space of the city and has achieved good results in regulating the urban climate and maintaining the ecological balance. After the 1990s, paving the pavement with pervious materials instead of traditional materials has become a common experience in urban construction in developed countries [15]. For example, Germany, which is known for its environmental protection technology, proposes to transform $90 \%$ of the roads in the country into pervious pavements by 2010. It can be seen that the pervious pavement is of great significance to the future development of the city.

Cement is the most basic raw material for engineering construction. At present, there is no material at home and abroad that can replace its status. Despite the rapid development of the cement industry, many problems have arisen, such as serious waste of resources, huge energy consumption, and serious pollution to the environment [16]. In addition, the carbon dioxide produced by the cement production causes global warming [17]. On the other hand, the dust emission in cement production is high, which will pollute the air, produce haze, and cause environmental pollution [18]. Reducing the amount of cement and finding possible cement substitutes is an important way to achieve sustainable development.

Fly ash is a kind of industrial by-product waste. It is the fine ash obtained from the coal combustion [19]. In China, the annual output of fly ash has reached 30 million tons. With the development of the power industry, the amount of fly ash discharged from coal-fired power plants has increased year by year. If the large amount of fly ash is not treated reasonably, it will generate dust and pollute the atmosphere; if it is discharged into the water system, it will cause river blockage, and the toxic chemicals will cause harm to human and other creatures [20]. Therefore, how to dispose and utilize fly ash has become a widely concerned issue. In China, as early as the 1950s, fly ash began to be used as a concrete and mortar admixture and pavement base material in construction and road engineering, especially in hydropower construction and dam projects [21]. In the 1960s, the utilization of fly ash began to shift to wall materials and the comprehensive utilization of fly ash was booming in the 1980s. Fly ash has also been used in other countries with different degrees. The UK has developed a high-quality commercial fly ash for reinforced concrete. Poland focused on the use of fly ash in building materials. The comprehensive utilization of fly ash in France started earlier, especially in the application of cement and concrete [21,22]. Australia attached great importance to the quality control system of fly ash concrete industry, and had a company specializing in high quality fly ash products [23]. Therefore, the utilization of fly ash and its application in roads and building materials cannot only realize waste utilization, but also reduce the amount of cement, which has high economic and environmental protection value.

The application of fly ash in cement concrete has many advantages, such as reducing cement consumption; improving the workability of concrete mixture; reducing creep, hydration heat, and thermal expansion of concrete; and improving the impermeability of concrete [24]. The effects of fly ash on cement concrete have been reported by many researchers. Wu et al. [25] investigated the effect of fly ash on the fresh and aged mechanical properties and durability of coral aggregate concrete, the compressive strength, splitting tensile strength, chloride penetration, and micro-hardness of the interfacial transition zone (ITZ) were measured, compared with the control group, the addition of fly ash improved the cohesiveness and water retention. On the other hand, fly ash had a negative effect on early-age strength, but significantly enhanced the long-term strength. Zhu et al. [26] conducted experiments on fly ash modified engineered cementitious composites (ECC), the ductility and compressive strength properties were tested. The results showed that the addition of fly ash reduced the compressive strength about $40 \%$, but it is positive in improving the ductility of ECC. Uthaman et al. [27] conducted experiments and investigated the strength and durability of fly ash 
concrete. The results indicated the early-age strength and durability of fly ash concrete were insufficient, but the long-term strength and durability were improved. The freeze-thaw resistance of high-performance concrete (HPC) modified by fly ash was investigated by Ma et al. [28], the result indicated the fly ash improved the freeze-thaw durability of HPC. In summary, fly ash has positive effect on the long-term mechanical property and durability of concrete, but it is negative for early-age strength.

However, the application of fly ash in pervious concrete is not as extensive as in ordinary concrete and the related researches are few. Muthaiyan and Thirumalai [29] studied the strength properties of pervious concrete modified by fly ash. The fly ash was used to replace cement at $10 \%$ and $20 \%$ levels, and the results showed that $28 \mathrm{~d}$ compressive strength and flexural strength of fly ash modified pervious concrete were significantly reduced, especially the mixture with $20 \%$ fly ash. Aoki et al. [30] investigated the compressive strength and permeability of pervious concrete modified by fly ash and the cement replacement levels were $20 \%$ and $50 \%$. The compressive strengths of $20 \%$ and $50 \%$ fly ash modified pervious concrete decreased $12.7 \%$ and $43.7 \%$, respectively. The permeability of pervious concrete was not affected by the addition of fly ash. Zaetang et al. [31] studied the fly ash modified pervious cement concrete. The cement was replaced by fly ash at different levels $(85,90$, 95 , and $100 \%$ ), the compressive strength and splitting tensile strength at the age of seven days were tested. The results indicated that the compressive strength and splitting tensile strength of fly ash modified pervious concrete decreased with the increasing fly ash content. When the fly ash content was $100 \%$, the maximum compressive strength and splitting tensile strength were $5.9 \mathrm{MPa}$ and $0.74 \mathrm{MPa}$, respectively. Peng et al. [32] investigated the compressive strength of fly ash modified pervious concrete at the age of 28 and 60 days with fly ash content of $30 \%$. The obvious decrease in compressive strength at $28 \mathrm{~d}$ was observed compared to the control mixture. Compressive strength at $60 \mathrm{~d}$ was comparable to the control group. The adverse effects of fly ash on the strength of pervious concrete were also reported by other researchers [33,34].

At present, the application of fly ash in ordinary concrete has been extensively studied. However, studies on the effects of fly ash on the properties of pervious concrete are relatively few, and the existing studies were mainly focused on the early-age (generally $28 \mathrm{~d}$ ) properties of fly ash modified pervious concrete. The long-term $(60 \mathrm{~d}, 90 \mathrm{~d}$, etc.) performance of fly ash modified pervious concrete has rarely been reported. Additionally, the freeze-thaw durability of fly ash modified pervious concrete was not studied extensively. Therefore, it is necessary to carry out research to investigate the strength properties at different ages and freeze-thaw durability of fly ash modified pervious concrete. Based on the previous researches conducted by our group [35,36], in order to evaluate the strength time-varying and freeze-thaw durability of fly ash modified pervious concrete, pervious concrete modified by fly ash was prepared with equivalent volume method, the porosity, permeability, strength at different ages and freeze-thaw durability of fly ash modified pervious concrete with different fly ash incorporation levels were studied. The conclusions obtained in this paper are helpful to understand the strength development with age and freeze-thaw durability of fly ash modified pervious concrete, and will provide reference for the research and application of fly ash in pervious concrete.

\section{Materials and Methods}

\subsection{Materials}

The raw materials used in the study were coarse aggregate, cement, fly ash, water, and superplasticizer. The type, size, and physical properties of coarse aggregate are shown in Table 1. Portland cement (P.O 42.5) was obtained from Jilin Yatai Cement Co., Ltd. (Jilin, China), and its physical properties are shown in Table 2. Fly ash of class C, with the density of $1988 \mathrm{~kg} / \mathrm{m}^{3}$, was purchased from Changchun FAW Co., Ltd. (Jilin, China). The chemical compositions of Portland cement and fly ash are shown in Table 3. The polycarboxylic acid superplasticizer produced by Shanxi Qinfen Building Material Co., Ltd. (Shanxi, China), was used to improve the workability of pervious concrete. 
Table 1. Properties of coarse aggregate.

\begin{tabular}{cc}
\hline Physical Property & Index \\
\hline Type & natural granite coarse aggregate \\
Size $(\mathrm{mm})$ & $4.75-9.5$ \\
Apparent density $\left(\mathrm{kg} / \mathrm{m}^{3}\right)$ & 2786 \\
Bulk density $\left(\mathrm{kg} / \mathrm{m}^{3}\right)$ & 1534 \\
Bulk porosity $(\%)$ & 44.9 \\
Crushing value $(\%)$ & 9.7 \\
Needle-like particle content $(\%)$ & 7.1 \\
Water absorption $(\%)$ & 1.63 \\
\hline
\end{tabular}

Table 2. Physical properties of Portland cement.

\begin{tabular}{|c|c|c|c|c|c|c|c|}
\hline \multirow{2}{*}{$\begin{array}{l}\text { Density } \\
\left(\mathrm{g} / \mathrm{cm}^{3}\right)\end{array}$} & \multirow{2}{*}{$\begin{array}{c}\text { Specific Surface } \\
\text { Area }\left(\mathrm{m}^{2} / \mathrm{kg}\right)\end{array}$} & \multicolumn{2}{|c|}{ Setting Time (min) } & \multicolumn{2}{|c|}{ Compressive Strength (MPa) } & \multicolumn{2}{|c|}{ Flexural Strength (MPa) } \\
\hline & & $\begin{array}{l}\text { Initial } \\
\text { Setting }\end{array}$ & $\begin{array}{l}\text { Final } \\
\text { Setting }\end{array}$ & $3 \mathrm{~d}$ & $28 \mathrm{~d}$ & $3 \mathrm{~d}$ & $28 \mathrm{~d}$ \\
\hline 2.96 & 342 & 182 & 251 & 21.8 & 47.6 & 4.7 & 7.5 \\
\hline
\end{tabular}

Table 3. Chemical composition of Portland cement and fly ash.

\begin{tabular}{ccccccc}
\hline \multirow{2}{*}{ Materials } & \multicolumn{7}{c}{ Chemical Composition (\%) } \\
\cline { 2 - 7 } & $\mathbf{S i O}_{\mathbf{2}}$ & $\mathbf{A l}_{\mathbf{2}} \mathbf{O}_{\mathbf{3}}$ & $\mathbf{C a O}$ & $\mathbf{M g O}$ & $\mathbf{F e}_{\mathbf{2}} \mathbf{O}_{\mathbf{3}}$ & $\mathbf{S O}_{\mathbf{3}}$ \\
\hline Cement & 22.6 & 5.6 & 62.7 & 1.7 & 4.3 & 2.5 \\
Fly ash & 51.3 & 22.8 & 10.7 & 2.8 & 6.9 & 1.9 \\
\hline
\end{tabular}

\subsection{Mix Design}

The mix of pervious concrete was designed with the volume method in accordance with the Chinese national standard CJJ/T 135-2009 [37]. Fly ash modified previous concrete was prepared in the experiment. In addition, pervious concrete without fly ash was prepared as the control pervious concrete. Fly ash was incorporated at different levels to partially replace the cement with equivalent volume method. The replacement levels were 3\%, 6\%, 9\%, and 12\%, respectively. In our previous work [35], the effects of porosity, water to binder ratio and coarse aggregate size on the strength properties, permeability and freeze-thaw resistance of pervious concrete have been studied with orthogonal experiment and the mix ratio of pervious concrete has been optimized. The optimum mix ratio was coarse aggregate size of $4.75-9.5 \mathrm{~mm}$, porosity of $15 \%$, and water to binder ratio of 0.30 , and this mix ratio was used in this study. In order to improve workability of pervious concrete, superplasticizer was used and the dosage was $0.8 \%$ of the cementitious material mass. The mix proportions are shown in Table 4.

Table 4. Mix proportions of fly ash modified pervious concrete (in $\mathrm{kg} / \mathrm{m}^{3}$ ).

\begin{tabular}{cccccc}
\hline Mix ID & Coarse Aggregate & Cement & Fly Ash & Water & Superplasticizer \\
\hline Control & 1503.3 & 479.9 & 0 & 144.0 & 3.84 \\
FA-3 & 1503.3 & 462.0 & 14.3 & 142.9 & 3.81 \\
FA-6 & 1503.3 & 444.3 & 28.4 & 141.8 & 3.78 \\
FA-9 & 1503.3 & 426.9 & 42.2 & 140.7 & 3.75 \\
FA-12 & 1503.3 & 409.8 & 55.9 & 139.7 & 3.73 \\
\hline
\end{tabular}

\subsection{Specimen Preparation}

According to the experiments, $100 \times 100 \times 400 \mathrm{~mm}$ prismatic specimen and $100 \times 100 \times 100 \mathrm{~mm}$ cubic specimen were prepared. In the control group, three prismatic specimens for $28 \mathrm{~d}-\mathrm{flexural}$ strength, three cubic specimens for porosity, permeability and $28 \mathrm{~d}$-compressive strength, and twelve cubic 
specimens for freeze-thaw cycles were needed. In the fly ash modified group, in addition to the same specimen as the control group, additional three prismatic specimens for $150 \mathrm{~d}$-flexural strength and three cubic specimens for $150 \mathrm{~d}$-compressive strength of each group were prepared. A total of 87 cubic specimens and 27 prismatic specimens were prepared in the lab for the experiments. The specimen curing conditions of different tests are shown in Figure 1.

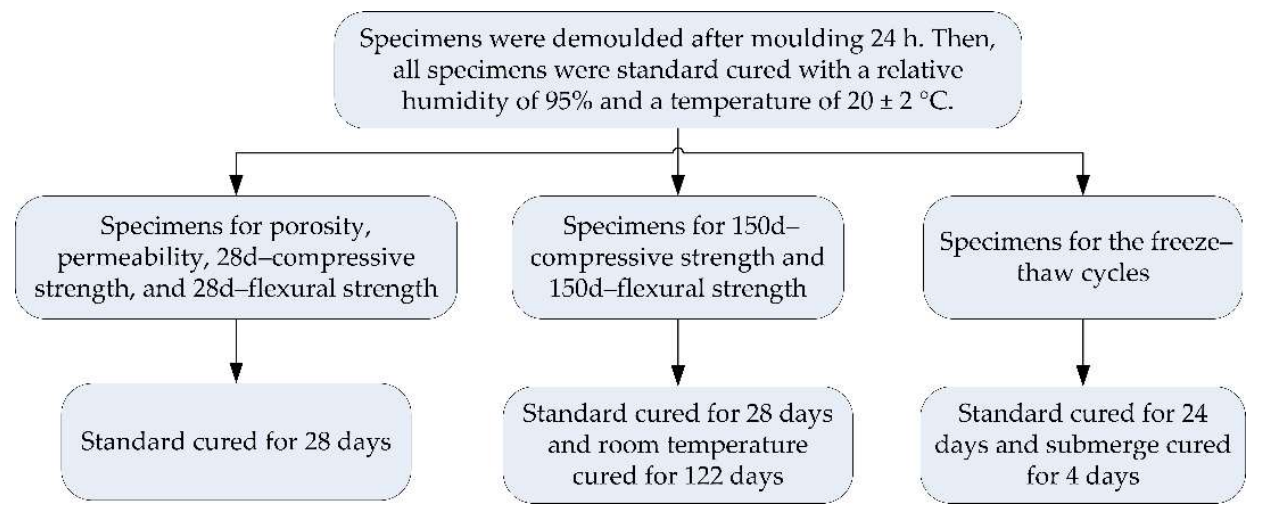

Figure 1. The specimen curing conditions of different tests.

\subsection{Testing Methods}

The effective porosities (proportion of open pore and semi-open pore) of all mixtures were tested with mass method. The effective porosity was characterized by the average of three specimens and determined by the following equation,

$$
P=\left(1-\frac{m_{1}-m_{0}}{V \rho}\right) \times 100 \%
$$

where $m_{0}$ is the mass of the specimen submerged in water $(\mathrm{g}) ; m_{1}$ is the saturated surface-dry mass of the specimen $(\mathrm{g}) ; \rho$ is the water density $\left(\mathrm{g} / \mathrm{cm}^{3}\right)$, and $\mathrm{V}$ is the volume of the specimen $\left(\mathrm{cm}^{3}\right)$.

The permeability coefficient was measured according to the national standard [37] with homemade instrument. The description of the permeability instrument is shown in Figure 2. The test procedures of permeability coefficient are described in Figure 3. In each group, the permeability was characterized by the average permeability coefficients of three specimens. The permeability coefficient can be calculated by the following equation, the specific parameters can be found in reference [36].

$$
k=\frac{Q L}{A H t}
$$

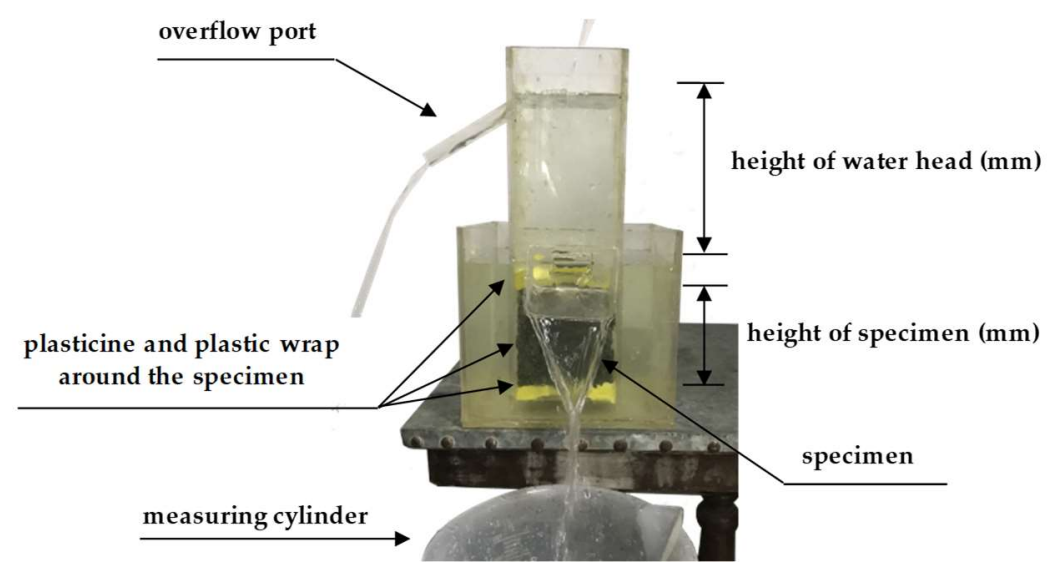

Figure 2. Homemade permeability measure instrument. 


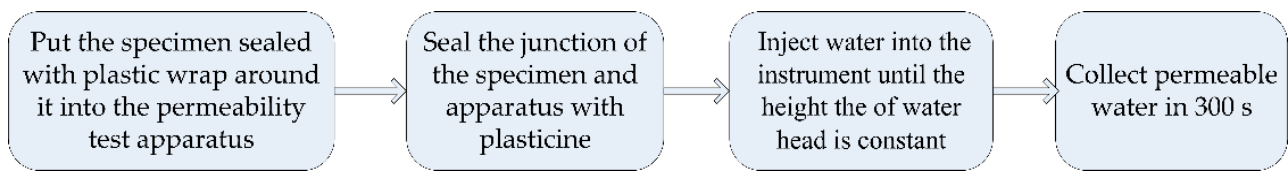

Figure 3. Test procedures of permeability coefficient.

Compressive strength and flexural strength tests were conducted in accordance with the Chinese national standard GB/T 50081-2002 [38]. The compressive strength test was conducted with a hydraulic pressure testing machine. The sides of the specimen were used as the bearing surface for the compressive strength test. The loading rate for compressive strength was $5 \mathrm{kN} / \mathrm{s}$ and the load was applied until the specimen broke. The flexural strength was conducted with a closed-loop, servo-controlled hydraulic testing system. Three-point bending test was adopted to determine the flexural strength. The loading point is located in the midspan of the specimen, and the distance between the two support-points is $300 \mathrm{~mm}$. The loading rate for flexural strength was $0.05 \mathrm{kN} / \mathrm{s}$. In each group, three specimens were tested and the average compressive strength and flexural strength were calculated to characterize the strength properties. The compressive strength and flexural strength can be calculated by following equations, the specific parameters can be found in [36].

$$
\begin{gathered}
f_{c}=\frac{F}{A} \\
f_{f}=\frac{3}{2} \frac{F L}{b h^{2}}
\end{gathered}
$$

The fast freezing method was adopted to conduct freeze-thaw cycles test based on the Chinese national standard GB/T 50082-2009 [39]. The test procedures can be described as: (a) place the prepared specimen into the specimen box and inject water into the box, the water should be $5 \mathrm{~mm}$ above the top surface of the specimen; (b) set the temperature and number of the freeze-thaw cycles; (c) conduct freeze-thaw test; (d) measure the compressive strength of the specimens after the specified number of freeze-thaw cycles. The level of freeze-thaw cycles was set to 25, 50, 75, and 100 cycles. In each freeze-thaw cycles level, three cubic specimens were used. The compressive strength after freeze-thaw cycles was measured and the compressive strength loss was chosen as the evaluation index for freeze-thaw resistance. The detailed explanation for choosing compressive strength loss can be found elsewhere [36]. The compressive strength after freeze-thaw cycles was characterized by the average strength of three specimens. Compressive strength loss at the corresponding level was calculated based on the compressive strength of specimens under 0 freeze-thaw cycle. The termination condition of freeze-thaw cycles was that the specimens underwent 100 cycles or the compressive strength loss exceeded $25 \%$. The specimens of fly ash modified pervious concrete after 75 freeze-thaw cycles are shown in Figure 4.

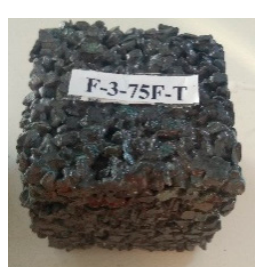

(a)

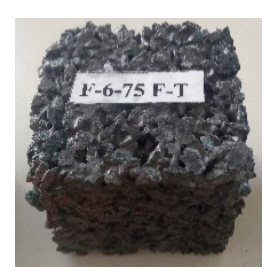

(b)

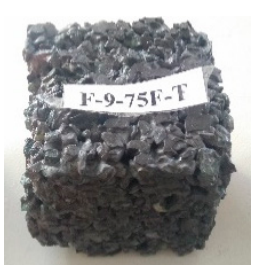

(c)

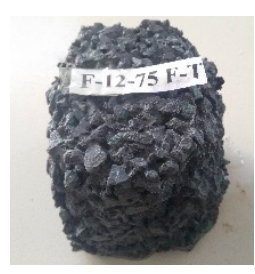

(d)

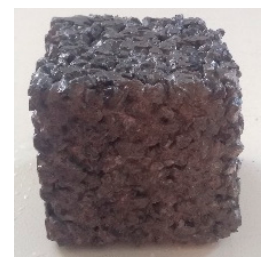

(e)

Figure 4. Fly ash modified specimens after 75 freeze-thaw cycles: (a) 3\% fly ash modified specimen; (b) $6 \%$ fly ash modified specimen; (c) 9\% fly ash modified specimen; (d) 12\% fly ash modified specimen; (e) control specimen. 


\section{Results and Discussion}

The summary of the compressive strength, flexural strength, porosity, and permeability results with the standard deviations are tabulated in Table 5, the freeze-thaw cycles results are shown in Table 6.

Table 5. Strength, permeability, and porosity results for fly ash modified pervious concrete.

\begin{tabular}{|c|c|c|c|c|c|c|c|c|c|c|c|c|}
\hline \multirow[t]{2}{*}{ Mix ID } & \multicolumn{2}{|c|}{ Porosity (\%) } & \multicolumn{2}{|c|}{$\begin{array}{c}\text { Permeability } \\
\text { Coefficient }(\mathrm{mm} / \mathrm{s})\end{array}$} & \multicolumn{2}{|c|}{$\begin{array}{c}28 \mathrm{~d} \mathrm{CS}^{1} \\
(\mathrm{MPa})\end{array}$} & \multicolumn{2}{|c|}{$\begin{array}{c}28 \mathrm{~d} \mathrm{FS}^{2} \\
(\mathrm{MPa})\end{array}$} & \multicolumn{2}{|c|}{$\begin{array}{c}150 \mathrm{~d} \mathrm{CS} \\
(\mathrm{MPa})\end{array}$} & \multicolumn{2}{|c|}{$\begin{array}{c}150 \mathrm{~d} \text { FS } \\
(\mathrm{MPa})\end{array}$} \\
\hline & Mean & $\mathrm{SD}^{3}$ & Mean & SD & Mean & SD & Mean & SD & Mean & SD & Mean & SD \\
\hline FA-3 & 14.1 & 0.2 & 3.94 & 0.15 & 20.0 & 0.57 & 4.39 & 0.10 & 21.5 & 0.59 & 4.77 & 0.09 \\
\hline FA-6 & 13.7 & 0.4 & 3.79 & 0.13 & 18.9 & 0.43 & 4.01 & 0.14 & 20.2 & 0.62 & 4.33 & 0.08 \\
\hline
\end{tabular}

${ }^{1}$ Compressive strength; ${ }^{2}$ Flexural strength; ${ }^{3}$ Standard deviations.

Table 6. Freeze-thaw cycle results of fly ash modified pervious concrete.

\begin{tabular}{ccccccccc}
\hline \multirow{2}{*}{ Mix ID } & \multicolumn{7}{c}{ Compressive Strength and Its Loss After Freeze-Thaw Cycles } \\
\cline { 2 - 8 } & $\begin{array}{c}\text { 25 Cycles } \\
\text { Compressive } \\
\text { Strength (MPa) }\end{array}$ & Loss (\%) & $\begin{array}{c}\text { 50 Cycles } \\
\text { Compressive } \\
\text { Strength (MPa) }\end{array}$ & Loss (\%) & $\begin{array}{c}\text { 75 Cycles } \\
\text { Compressive } \\
\text { Strength (MPa) }\end{array}$ & Loss (\%) & $\begin{array}{c}\text { Compressive } \\
\text { Strength (MPa) }\end{array}$ & $\begin{array}{c}\text { Loss (\%) } \\
\text { Lencles }\end{array}$ \\
\hline Control & 21.2 & 4.5 & 18.1 & 18.5 & 16.7 & 24.8 & 14.2 & 36.0 \\
FA-3 & 18.8 & 6.0 & 16.4 & 18.0 & 14.8 & 26.0 & - \\
FA-6 & 17.5 & 7.4 & 15.2 & 19.6 & 13.9 & 26.5 & - \\
FA-9 & 15.1 & 7.4 & 12.8 & 21.5 & 11.5 & 29.4 & - \\
FA-12 & 13.5 & 8.2 & 10.7 & 27.2 & - & - & - \\
\hline
\end{tabular}

\subsection{Porosity and Permeability}

The effective porosities of fly ash modified pervious concrete are shown in Figure 5. As can be seen, the incorporation levels of fly ash had little effect on the effective porosity of fly ash modified pervious concrete. This is because the cement was partially replaced by fly ash with equivalent volume method, thus the addition of fly ash did not cause the pore volume changes of the specimen. In addition, the effective porosities measured of all mixtures were less than the designed porosity of $15 \%$. The pore in previous concrete is composed of open pore, semi-open pore, and closed pore, the effective porosity only included open and semi-open pore, so the effective porosity was generally lower than the total porosity.

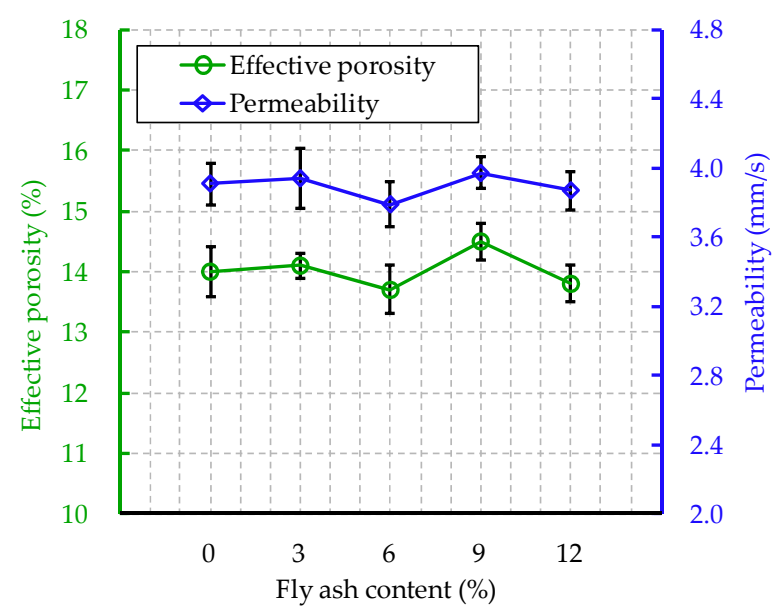

Figure 5. The effective porosity and permeability of fly ash modified pervious concrete versus fly ash content.

The permeability coefficients of fly ash modified pervious concrete are also shown in Figure 5. From Figure 5, it can be concluded that the permeability coefficients were not affected by the dosage of 
fly ash. The permeability coefficients of all groups were about $3.8 \mathrm{~mm} / \mathrm{s}$, which is met the standard requirement of $0.5 \mathrm{~mm} / \mathrm{s}$ for pervious concrete in the national standard [37]. Just as reported in the literature [35], the porosity was the most important and direct factor that determined the permeability coefficient of pervious concrete, when the porosity did not change, the permeability would not change.

\subsection{Compressive Strength}

The compressive strength of the fly ash modified pervious concrete is shown in Figure 6. It can be seen that the addition of fly ash reduced both $28 \mathrm{~d}-$ and 150-compressive strengths of the pervious concrete. With the increasing amount of fly ash, the $28 \mathrm{~d}$-compressive strength of fly ash modified pervious concrete decreased rapidly. When the addition of fly ash changed from $0 \%$ to $12 \%$, the compressive strength decreased from $22.2 \mathrm{MPa}$ to $14.7 \mathrm{MPa}$, the compressive strength reduction was $7.5 \mathrm{MPa}$ with the loss ratio of $33.8 \%$. The adverse effect of fly ash on the $28 \mathrm{~d}$-compressive strength has been also reported by other researchers. The main reason for the decrease in compressive strength caused by fly ash was, on one hand, the fly ash was added to partially replace the cement, which caused the decrease in the amount of cement. The decrease of cement resulted in the decrease of cement binder used to coat the aggregate and reduced the bonding force between aggregates. On the other hand, due to the water demand of fly ash, if there was no supplemental water, the addition of fly ash would reduce the water required for cement hydration. The reduction in water influenced the cement hydration degree and the incomplete cement hydration [40] weakened the bonding between coarse aggregates. All these decreased the compressive strength of fly ash modified pervious concrete. Compared with the control group, the $28 \mathrm{~d}$-compressive of fly ash modified pervious concrete was obviously lower.

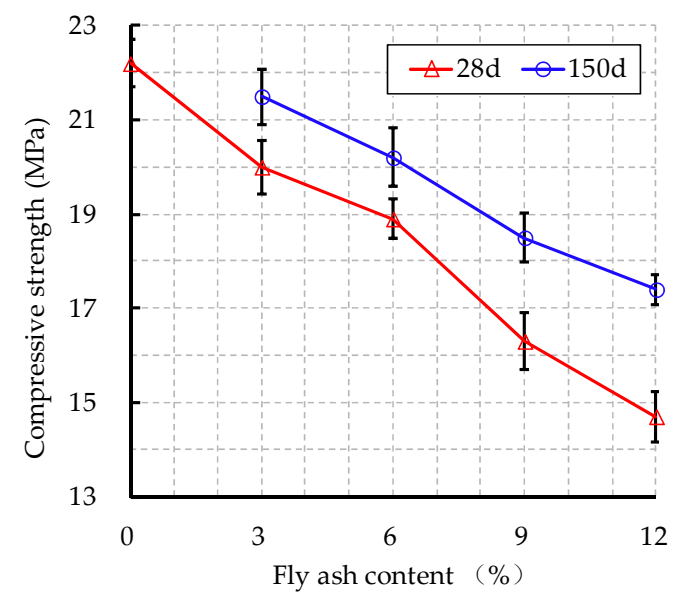

Figure 6. Compressive strength of fly ash modified pervious concrete versus fly ash content.

The $150 \mathrm{~d}$-compressive strength of fly ash modified pervious concrete increased at all addition levels compared to the $28 \mathrm{~d}$-compressive strength. The $3 \%$ fly ash modified group had the maximum $150 \mathrm{~d}$-compressive strength of $21.5 \mathrm{MPa}$, which was comparable to the control group with compressive strength of $22.2 \mathrm{MPa} .12 \%$ fly ash modified group had the $150 \mathrm{~d}$-compressive strength of $17.4 \mathrm{MPa}$. The increases of compressive strength between $28 \mathrm{~d}$ - and $150 \mathrm{~d}$-compressive strength were $2.7 \mathrm{MPa}$ at $12 \%$ incorporation level and $1.5 \mathrm{MPa}$ at $3 \%$ incorporation level. This was because the $\mathrm{SiO}_{2}$ in fly ash reacted with the cement hydration product $\left(\mathrm{Ca}(\mathrm{OH})_{2}\right)$ and formed a pozzolanic $\mathrm{C}-\mathrm{S}-\mathrm{H}$ gel, which improved the bonding between the hardened cement binder and the aggregate. The higher the fly ash content, the more C-S-H gel. Thus, the compressive strength increase of high fly ash content group was higher than that of low fly ash content group. The reason for the increase in $150 \mathrm{~d}$-compressive strength of fly ash-modified permeable concrete was that, as the age increased, the cement was further hydrated and the hydration degree increased gradually, the adhesion property of the cementitious material increased and the bonding force between aggregates enhanced, thus the 
compressive strength was increased. Although the addition of fly ash reduced the compressive strength of pervious concrete, the $28 \mathrm{~d}$-compressive strength of fly ash modified pervious concrete with $12 \%$ fly ash content still reached $14.7 \mathrm{MPa}$, which could fully meet the requirements of non-loaded pavements, such as pedestrian path, parking lots, and park roads.

\subsection{Flexural Strength}

Figure 7 shows the flexural strength of fly ash modified pervious concrete versus fly ash content. Just as the effect of fly ash on the compressive strength, fly ash also had adverse effect on the flexural strength of pervious concrete. The addition of fly ash reduced the $28 \mathrm{~d}-$ and $150 \mathrm{~d}$-flexural strength of fly ash modified pervious concrete significantly. The higher the fly ash content, the lower the flexural strength of fly ash modified pervious concrete. Compared to the control group with the flexural strength of $4.84 \mathrm{MPa}$, when the fly ash content was $12 \%$, the minimum $28 \mathrm{~d}$-flexural strength of fly ash modified pervious concrete was $3.54 \mathrm{MPa}$ and the flexural strength loss was $26.9 \%$. Although the addition of fly ash reduced the flexural strength of the pervious concrete, the $28 \mathrm{~d}$-flexural strength of fly ash modified pervious concrete still met the requirements of $2.5 \mathrm{MPa}$ in the national standard [37]. The reduction in $28 \mathrm{~d}$-flexural strength was also ascribed to the weak bonding between coarse aggregates caused by the reduction in cement consumption and incomplete cement hydration [40]. The $150 \mathrm{~d}$-flexural strength of fly ash modified pervious concrete also increased compared to the $28 \mathrm{~d}$-flexural strength at all incorporation levels, and the maximum increase was $0.39 \mathrm{MPa}$. The 3\% fly ash content group had the $150 \mathrm{~d}$-flexural strength of $4.77 \mathrm{MPa}$, which was $98 \%$ of the flexural strength of the control group. The relationship between compressive strength and flexural strength of fly ash modified pervious concrete can be found in Figure 8. There was a good linear relationship between compressive strength and flexural strength and the correlation coefficient between them was 0.93 .

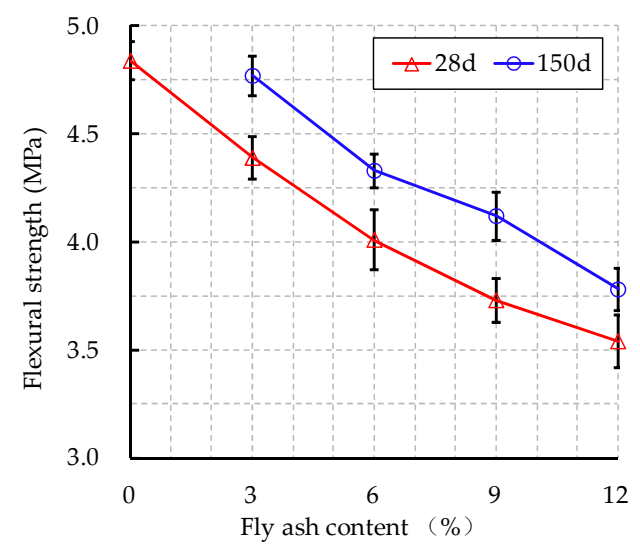

Figure 7. Flexural strength of fly ash modified pervious concrete versus fly ash content.

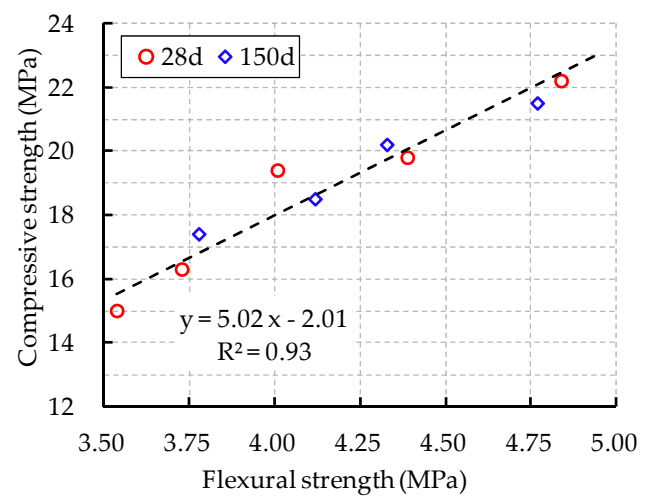

Figure 8. Relationship between flexural strength and compressive strength of fly ash modified pervious concrete. 
It can be seen from the above results that the compressive strength and flexural strength of fly ash modified pervious concrete had a great relationship with the age, and the strength gradually increased with the increasing age. The early-age strengths were low and the long-term strengths could achieve desired increase. The strength time-varying was existed for fly ash modified pervious concrete, which was consistent with what has been reported in fly ash modified ordinary concrete.

\subsection{Freeze-Thaw Resistance}

Figure 9 shows the relationship between compressive strength and freeze-thaw cycles of fly ash modified pervious concrete. The compressive strengths of all fly ash modified groups decreased with the increasing freeze-thaw cycles, which indicated the freeze-thaw resistance of fly ash modified pervious concrete was reduced. Compressive strength of $12 \%$ fly ash modified group rapidly decreased from $14.7 \mathrm{MPa}$ to $10.7 \mathrm{MPa}(27.2 \%$ strength loss) under 50 freeze-thaw cycles. The compressive strength losses of fly ash modified pervious concrete under freeze-thaw cycles are shown in Figure 10. Based on Figure 10, it can be concluded that the compressive strength losses of fly ash modified pervious concrete increased with the increase of freeze-thaw cycles. When the freeze-thaw cycles were same, the compressive strength losses of fly ash modified pervious concrete increased with the increasing content of fly ash. Compared with the control group, fly ash modified pervious concrete had higher compressive strength loss, and the higher the fly ash incorporation level, the higher the compressive strength loss, which indicated that the addition of fly ash was negative to the freeze-thaw resistance of pervious concrete. The freeze-thaw resistance of fly ash modified pervious concrete with different fly ash incorporation level was quite different, the compressive strength loss of $12 \%$ fly ash modified group rapidly exceeded $25 \%$ just undergoing 50 freeze-thaw cycles, the other three fly ash modified mixtures only experienced 75 freeze-thaw cycles. Compared to the control group, the addition of fly ash reduced the freeze-thaw resistance of pervious concrete. Figure 4 shows the fly ash modified pervious concrete specimens after 75 freeze-thaw cycles. Based on Figure 4, we can see that the specimen appearance features of control group and fly ash modified groups were obviously different. The specimen shape of control group under 75 freeze-thaw cycles was basically intact, but for the specimens of fly ash modified pervious concrete, the mass loss appeared at different degrees, especially the specimens with $12 \%$ fly ash content. This is mainly because the addition of fly ash decreased the bonding between the aggregates, which resulted in easy deterioration and decay of freeze-thaw resistance.

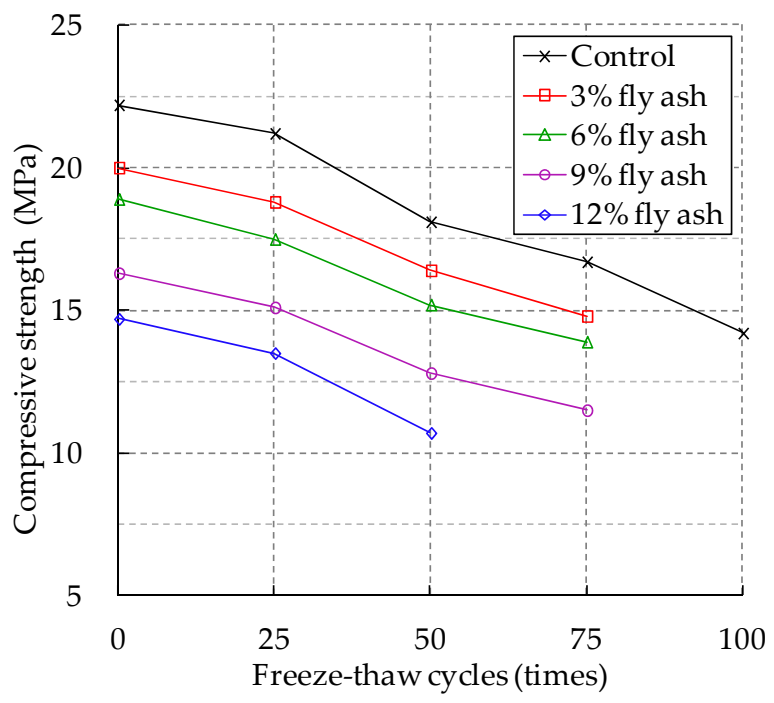

Figure 9. Compressive strength of fly ash modified pervious concrete under freeze-thaw cycles. 


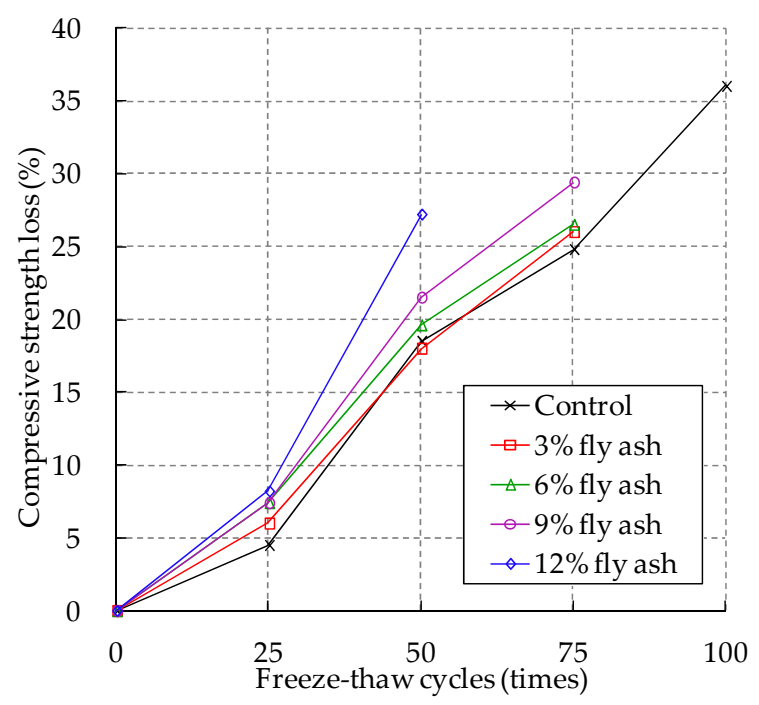

Figure 10. Compressive strength loss of fly ash modified pervious concrete under freeze-thaw cycles.

\section{Conclusions}

Sustainable pavement materials-fly ash modified pervious concrete, were prepared and investigated in the lab. Porosity, permeability, early-age (28 d) strength, long-term (150 d) strength, and freeze-thaw resistance of pervious concrete were tested. The influences of fly ash on pervious concrete properties were analyzed. Based on test results, the following conclusions can be drawn.

- The fly ash modified pervious concrete designed with equivalent volume replacement of cement did not affect the effective porosity, thus the permeability of pervious concrete hardly changed with the content of fly ash compared to the unmodified control pervious concrete.

- The early-age compressive strength and flexural strength of fly ash modified pervious concrete was decreased by the addition of fly ash. The higher content of fly ash, the lower compressive strength and flexural strength. Compared to the early-age compressive strength and flexural strength, the long-term compressive strength and flexural strength increased at all fly ash incorporation levels, which indicated that the age had an important effect on the strengths of fly ash modified pervious concrete.

- The addition of fly ash significantly decreased the freeze-thaw resistance of pervious concrete. The compressive strength loss of fly ash modified pervious concrete under freeze-thaw cycles was higher than the unmodified control pervious concrete. The freeze-thaw resistance of fly ash modified pervious concrete decreased with the increasing fly ash content.

- Although fly ash was not positive to the properties of pervious concrete, it was still feasible to apply fly ash as a substitute for cement in pervious concrete.

Author Contributions: Conceptualization: H.L.; investigation: G.L., H.L., and Y.G.; Writing (original draft): G.L. and L.W.; Writing (review and editing): Y.G.

Funding: This research was funded by the Science Technology Development Program of Jilin Province (grant number 20180201026SF) and the Transportation Science and Technology Program of Jilin Province (grant number 2018-1-9).

Acknowledgments: The authors would like to appreciate anonymous reviewers for their constructive suggestions and comments to improve the quality of the paper.

Conflicts of Interest: The authors declare no conflict of interest. 


\section{References}

1. Hu, M.C.; Zhang, X.Q.; Siu, Y.L.; Li, Y.; Tanaka, K.; Yang, H. Flood mitigation by permeable pavements in Chinese sponge city construction. Water 2018, 10, 172. [CrossRef]

2. Liu, H.; Jia, Y.W.; Niu, C.W. “Sponge city” concept helps solve China's urban water problems. Environ. Earth. Sci. 2017, 76, 473. [CrossRef]

3. Ho, H.L.; Huang, R.; Hwang, H.C.; Lin, W.T.; Hsu, H.W. Waste-based pervious concrete for climate-resilient pavements. Materials 2018, 11, 900. [CrossRef] [PubMed]

4. Chandrappa, A.K.; Biligiri, K.P. Pervious concrete as a sustainable pavement material-Research findings and future prospects: A state-of-the-art review. Constr. Build. Mater. 2016, 111, 262-274. [CrossRef]

5. Li, J.S.; Zhang, Y.; Liu, G.L.; Peng, X.H. Preparation and performance evaluation of an innovative pervious concrete pavement. Constr. Build. Mater. 2017, 138, 479-485. [CrossRef]

6. Richards, D.R.; Edwards, P.J. Using water management infrastructure to address both flood risk and the urban heat island. Int. J. Water. Resour. Dev. 2017, 34, 490-498. [CrossRef]

7. Zhu, Z.H.; Chen, X.H. Evaluating the effects of low impact development practices on urban flooding under different rainfall intensities. Water 2017, 9, 548. [CrossRef]

8. Du, S.Q.; Shi, P.J.; Rompaey, A.V.; Wen, J.H. Quantifying the impact of impervious surface location on flood peak discharge in urban areas. Nat. Hazards 2015, 76, 1457-1471. [CrossRef]

9. Wei, T.; Wijesiri, B.; Jia, Z.L.; Li, Y.X.; Goonetilleke, A. Re-thinking classical mechanistic model for pollutant build-up on urban impervious surfaces. Sci. Total Environ. 2019, 651, 114-121. [CrossRef]

10. Neithalath, N.; Sumanasooriya, M.S.; Deo, O. Characterizing pore volume, sizes, and connectivity in pervious concretes for permeability prediction. Mater. Charact. 2010, 61, 802-813. [CrossRef]

11. Putman, B.J.; Neptune, A.I. Comparison of test specimen preparation techniques for pervious concrete pavements. Constr. Build. Mater. 2011, 25, 3480-3485. [CrossRef]

12. Liu, R.T.; Liu, H.J.; Sha, F.; Yang, H.L.; Zhang, Q.S.; Shi, S.S.; Zheng, Z. Investigation of the porosity distribution, permeability, and mechanical performance of pervious concretes. Processes 2018, 6, 78. [CrossRef]

13. Ngohpok, C.; Sata, V.; Satiennam, T.; Klungboonkrong, P.; Chindaprasirt, P. Mechanical properties, thermal conductivity, and sound absorption of pervious concrete containing recycled concrete and bottom ash aggregates. KSCE J. Civ. Eng. 2018, 22, 1369-1376. [CrossRef]

14. Nguyen, D.H.; Sebaibi, N.; Boutouil, M.; Leleyter, L.; Baraud, F. A modified method for the design of pervious concrete mix. Constr. Build. Mater. 2014, 73, 271-282. [CrossRef]

15. Korat, K.L.; Ducman, V.; Netinger, I. Influence of aggregate type and size on properties of pervious concrete. Constr. Build. Mater. 2015, 78, 69-76.

16. Wang, L.; Yang, H.Q.; Dong, Y.; Chen, E.; Tang, S.W. Environmental evaluation, hydration, pore structure, volume deformation and abrasion resistance of low heat Portland (LHP) cement-based materials. J. Clean. Prod. 2018, 203, 540-558. [CrossRef]

17. Xu, X.N.; Yang, Y.L.; Xiao, C.; Zhang, X.M. Energy balance and global warming potential of corn straw-based bioethanol in China from a life cycle perspective. Int. J. Green Energy 2018, 15, 296-304. [CrossRef]

18. Pellecchia, M.; Negri, I. Particulate matter collection by honey bees (Apis mellifera, L.) near to a cement factory in Italy. PeerJ 2018, 6, e5322. [CrossRef]

19. Wang, C.Y.; Olsson, G.; Liu, Y. Coal-fired power industry water-energy-emission nexus: A multi-objective optimization. J. Clean. Prod. 2018, 203, 367-375. [CrossRef]

20. Temuujin, J.; Surenjav, E.; Ruescher, C.H.; Vahlbruch, J. Processing and uses of fly ash addressing radioactivity (critical review). Chemosphere 2019, 216, 866-882. [CrossRef]

21. Blissett, R.S.; Rowson, N.A. A review of the multi-component utilization of coal fly ash. Fuel 2012, 97, 1-23. [CrossRef]

22. Yao, Z.T.; Ji, X.S.; Sarker, P.K.; Tang, J.H.; Ge, L.Q.; Xia, M.S.; Xi, Y.Q. A comprehensive review on the applications of coal fly ash. Earth Sci. Rev. 2015, 141, 105-121. [CrossRef]

23. Karthik, A.; Sudalaimani, K.; Vijayakumar, C.T.; Saravanakumar, S.S. Effect of bio-additives on physico-chemical properties of fly ash-ground granulated blast furnace slag based self cured geopolymer mortars. J. Hazard. Mater. 2019, 361, 56-63. [CrossRef] [PubMed]

24. Kurda, R.; Silvestre, J.D.; Brito, J. Life cycle assessment of concrete made with high volume of recycled concrete aggregates and fly ash. Resour. Conserv. Recyc 2018, 139, 407-417. [CrossRef] 
25. Wu, W.J.; Wang, R.; Zhu, C.Q.; Meng, Q.S. The effect of fly ash and silica fume on mechanical properties and durability of coral aggregate concrete. Constr. Build. Mater. 2018, 185, 69-78. [CrossRef]

26. Zhu, Y.; Zhang, Z.C.; Yang, Y.G.; Yao, Y. Measurement and correlation of ductility and compressive strength for engineered cementitious composites (ECC) produced by binary and ternary systems of binder materials: Fly ash, slag, silica fume and cement. Constr. Build. Mater. 2014, 68, 192-198. [CrossRef]

27. Uthaman, S.; Vishwakarma, V.; George, R.P.; Ramachandran, D.; Kumari, K.; Preetha, R.; Premila, M.; Rajaraman, R.; Kamachi Mudali, U.; Amarendra, G. Enhancement of strength and durability of fly ash concrete in seawater environments: Synergistic effect of nanoparticles. Constr. Build. Mater. 2018, 187, 448-459. [CrossRef]

28. Ma, H.X.; Yu, H.F.; Li, C.; Tan, Y.S.; Cao, W.T.; Da, B. Freeze-thaw damage to high-performance concrete with synthetic fibre and fly ash due to ethylene glycol deicer. Constr. Build. Mater. 2018, 187, 197-204. [CrossRef]

29. Muthaiyan, U.M.; Thirumalai, S. Studies on the properties of pervious fly ash-cement concrete as a pavement material. Cogent Eng. 2017, 4, 1318802. [CrossRef]

30. Aoki, Y.; Sri Ravindrarajah, R.; Khabbaz, H. Properties of pervious concrete containing fly ash. Road Mater. Pavement Des. 2012, 13, 1-11. [CrossRef]

31. Zaetang, Y.; Wongsa, A.; Sata, V.; Chindaprasirt, P. Use of coal ash as geopolymer binder and coarse aggregate in pervious concrete. Constr. Build. Mater. 2015, 96, 289-295. [CrossRef]

32. Peng, H.; Yin, J.; Song, W.M. Mechanical and hydraulic behaviors of Eco-friendly pervious concrete incorporating fly ash and blast furnace slag. Appl. Sci. 2018, 8, 895. [CrossRef]

33. Perez, L.S.; Hwang, S. Mix design and pollution control potential of pervious concrete with non-compliant waste fly ash. J. Environ. Manag. 2016, 176, 112-118. [CrossRef] [PubMed]

34. Carrasquillo, V.L.; Hwang, S. Comparative assessment of pervious concrete mixtures containing fly ash and nanomaterials for compressive strength, physical durability, permeability, water quality performance and production cost. Constr. Build. Mater. 2017, 139, 148-158. [CrossRef]

35. Liu, H.B.; Luo, G.B.; Wei, H.B.; Yu, H. Strength, permeability, and freeze-thaw durability of pervious concrete with different aggregate sizes, porosities, and water-binder ratios. Appl. Sci. 2018, 8, 1217. [CrossRef]

36. Liu, H.B.; Luo, G.B.; Gong, Y.F.; Wei, H.B. Mechanical properties, permeability, and freeze-thaw resistance of pervious concrete modified by waste crumb rubbers. Appl. Sci. 2018, 8, 1843. [CrossRef]

37. Ministry of Housing and Urban-Rural Construction of the People's Republic of China. Technical Specification for Pervious Cement Concrete Pavement; Ministry of Housing and Urban-Ural Construction of the People's Republic of China: Beijing, China, 2009. (In Chinese)

38. Ministry of Housing and Urban-Rural Construction of the People's Republic of China. Standard for Test. Method of Mechanical Properties on Ordinary Concrete; Ministry of Housing and Urban-Ural Construction of the People's Republic of China: Beijing, China, 2002. (In Chinese)

39. Ministry of Housing and Urban-Rural Construction of the People's Republic of China. Standard for Test. Methods of Long-Term Performance and Durability of Ordinary Concrete; Ministry of Housing and Urban-Ural Construction of the People's Republic of China: Beijing, China, 2009. (In Chinese)

40. Neville, A.M. Property of concrete, 4th ed.; China Architecture and Building Press: Beijing, China, 2009; pp. 199-203. ISBN 9787112127436.

(C) 2018 by the authors. Licensee MDPI, Basel, Switzerland. This article is an open access article distributed under the terms and conditions of the Creative Commons Attribution (CC BY) license (http:/ / creativecommons.org/licenses/by/4.0/). 